\title{
PENGUATAN BUDAYA KERJA PENYULUH AGAMA NON-PNS DALAM PEMBINAAN UMAT HINDU DI KABUPATEN GIANYAR
}

\author{
Oleh \\ I Nyoman Sueca \\ Dosen Fakultas Dharma Acarya \\ Institut Hindu Dharma Negeri Denpasar
}

\begin{abstract}
ABSTRAK
Peningkatan sumber daya dan kemajuan umat Hndu di kabupaten Gianyar nampaknya memerlukan sebuah proses, usaha pemerintah dalam peningkatan sumber daya manusia baik dalam bidang pembangunan dan pendidikan keagama, semua itu tidak lepas dari kesiapan pemimpin pada suatu organisasi dalam menyediakan pelayanan.

Dalam pengelolaan bidang pembinaan umat Hindu oleh penyuluh Non-PNS, guna terciptanya penguatan budaya kerja, dalam proses pencapaian kemajuan, meningkatnya sumber daya manusia di bidang agama dan keagamaan, maka diperlukan komitmen dan upaya dari penyuluh untuk menjalankan tugas dan kewajibannya sebagai pelayan masyarakat, yang merupakan wujud dari karma marga.

Upaya untuk meningkatkan pendidikan secara intlektual pembinaan-pembinaan penyuluh terhdahap umat Hindu terus ditingkatkan demi mencerdaskan dan memajukan umat Hindu di kabupatern Gianyar. Hal ini dilakukan sesuai dengan Undang-Undang No. 20 Tahun 2003, pasal 30, ayat 2 menyatakan bahwa pendidikan keagamaan berfungsi mempersiapkan peserta didik menjadi anggota masyarakat yang memahami dan mengamalkan nilai-nilai ajaran agama. Penguatan budaya kerja penyuluh menjadikan efisien efektif, apa bila penyuluh telah melakukan kinerja sesuati dengan terjadwal. Budaya organisasi dalam sebuah lembaga baik pemerintah maupun swasta yang diterapkan dengan kuat dan positif akan menjadikan manajemen secara efisien dan efektif, karena menghasilkan hal-hal seperti; nilai, prilaku, adanya musyawarah, dan kegiatan berorientasi pada misi.
\end{abstract}

Kata Kunci: Penguatan budaya kerja penyuluh Non-PNS.

\section{ABSTRACT}

Increasing the resources and progress of the Hndu people in Gianyar district seems to require a process, the government's efforts in improving human resources both in the area of development and religious education, all of which can not be separated from the readiness of leaders in an organization in providing services.

In the management of the field of guidance of Hindus by non-civil servants, in order to create the strengthening of work culture, in the process of achieving progress, the increase of human resources in religion and religion, it is necessary commitment and efforts from extension workers to carry out their duties and obligations as public servants is a manifestation of clan karma.

Efforts to improve the education of intlektual coaching-extension of Hindu entrepreneurs continue to be improved in order to educate and promote the Hindus in Gianyar regency. This is done in accordance with Law no. 20 of 2003, article 30, paragraph 2 states that religious education serves to prepare students to become members of the community who understand and practice the values of religious teachings.

Penguatan Budaya Kerja Penyuluh Agama Non-PNS

dalam Pembinaan Umat Hindu di Kabupaten Gianyar 
Strengthening the work culture of the counselor makes efficient effectiveness, what if the extension officer has performed performance sesuati with scheduled. Organizational culture in a government or private institution that is applied strongly and positively will make management efficient and effective, because it produces things like; values, behaviors, deliberations, and mission-oriented activities.

Keywords: Strengthening the work culture of Non-PNS extension workers.

\section{PENDAHULUAN}

Peningkatan sumber daya dan kemajuan umat Hindu di kabupaten Gianyar nampaknya memerlukan sebuah proses, usaha pemerintah dalam peningkatan sumber daya manusia baik dalam bidang-bidang pembangunan dan pendidikan keagama, semua itu tidak lepas dari kesiapan pemimpin pada suatu organisasi dalam menyediakan pelayanan yang mampu bersaing dalam era global seperti saat ini. Kualitas pemimpin yang baik adalah sebagai dasar utama dalam menyiapkan sumber daya manusia yang mampu bersaing dalam dunia global, tentunya diperlukan pengelolaan secara profesional dalam bidang pembinaan umat Hindu oleh penyuluh agama Hindu baik, penyuluh non-PNS maupun penyuluh yang bersetatus PNS.

Proses pencapaian kemajuan pendidikan khususnya di kabupaten gianyar telah menyelenggarakan pendidikan nonformal atau disebut pendidikan luar sekolah (pasraman), semua itu tidak lepas dan budaya kerja pemimpin pada suatu organisasi dalam menyediakan pelayanan yang mampu bersaing demi kemajauan umat Hindu. Kuatnya budaya kerja penyuluh sebagai pudamental dalam menyiapkan sumber daya manusia yang mampu bersaing dalam dunia global, tentunya diperlukan pengelolaan secara profesional dalam bidang pendidikan terutama di tingkat pendidikan dasar menengah.

Dalam pengelolaan bidang pembinaan umat Hindu oleh penyuluh non-PNS, guna terciptanya penguatan budaya kerja, dalam proses pencapaian kemajuan, meningkatnya sumber daya manusia di bidang agama dan keagamaan, maka diperlukan komitmen dan upaya dari penyuluh untuk menjalankan tugas dan kewajibannya sebagai pelayan masyarakat, yang merupakan wujud dari karma marga.

Upaya untuk meningkatkan pendidikan secara intlektual pembinaan-pembinaan penyuluh terhdahap umat Hindu terus ditingkatkan demi mencerdaskan dan memajukan umat Hindu di kabupatern Gianyar. Hal ini dilakukan sesuai dengan Undang-Undang No. 20 Tahun 2003, pasal 30 , ayat 2 menyatakan bahwa pendidikan keagamaan berfungsi mempersiapkan peserta didik menjadi anggota masyarakat yang memahami dan mengamalkan nilai-nilai ajaran agama. Ayat 3 berbunyi pendidikan keagamaan dapat diselenggarakan pada jalur pendidikan formal, non formal dan informal .

Sampai saat ini permasalahan pembinaan umat Hindu di kabupaten Gianyar khususnya pada jenjang birokrasi masih sangat dilematis, artinya pembinaan umat Hindu oleh tenaga penyuluh Non- PNS masih dalam bentuk teori dan rapi administrasi, namun secara praktinya masih belum mampu mencapai yang merupakan harapan masyarakat, sehingga akan berdampak terhadap pembangunan spiritual, sosial budaya dan perekonomian. Jumlah penyuluh agama Hindu Non-PNS berjumlah 65 orang dengan jumlah penduduk yang mayoritas beragama Hindu dan terdiri dari 72 desa adat. Untuk memperlancar kinerja Kepala Kantor Kementerian Agama kabupaten Gianyar, yang terkait dengan pembinaan umat Hindu, maka diangkatlah penyuluh agama Hindu non-PNS berdasarkan SK Kakanwil 
Kementerian Agama Provinsi Bali, No 07 Tahun 2016 tentang penetapan penyuluh agama Hindu non-PNS dilingkungan Kantor Kementerian Agama kabupaten Gianyar.

Untuk transparansi pejabat di lingkungan Kementerian Agama, tentang pengangkatan penyuluh non-PNS untuk pembinaan umat dilakukan perekruttannya dengan mengikuti prover tes. Upah yang diterima penyuluh non-PNS sangat minim tidak sesuai dengan upah minimum regional (UMR) dan lokasi pembinaan cukup jauh dari tempat tinggal. Hal inilah penyuluh agama memiliki suatu resiliensi sebagai sebuah acuan dalam menjalankan swadharmanya sebagai penyuluh agama untuk melakukan pembinaan kepada umat Hindu di daerah kabupaten Gianyar yang merupakan daerah berbudaya dan seni, dengan tujuan untuk meningkatkan pengetahuan agama dan ketrampilan keagamaan.

Penguatan budaya kerja menjadikan efisien efektif, menurut Deal dan Kennedy dalam (Doradjat, 2015: 61) menyatakan budaya organisasi dalam sebuah lembaga baik pemerintah maupun swasta yang diterapkan dengan kuat dan positif akan menjadikan manajemen efisien dan efektif karena menghasilkan hal-hal sebagai berikut: 1) Nilai yang saling menjamin tersosialisasikan, menjiwai para anggota dan merupakan kekuatan yang tidak nampak; 2) Prilaku pegawai secara tak disadari terkoordinasi oleh kekuatan yang informal; 3) Para anggota atau pegawai merasa komit dan loyal pada instansi atau organisasi; 4) adanya musyawarah dan kebersamaan dalam hal yang berarti sebagai bentuk partisipasi; dan 5) Semua kegiatan berorientasi kepada misi atau tujuan instansi atai oerganisasi.

Penyuluh agama Hindu Non-PNS di Gianyar yang direkrut oleh Kementerian Agama kabupaten Gianyar mengacu pada terbitnya peraturan Mentri Agama RI Nomor 56 tahun 2014 tentang pendidikan keagamaaan
Hindu, dimana bimas Hindu melaksanakan pendidikan agama dan keagamaan Hindu. Perekrutan tenaga penyuluh terkait dengan kualifikasi pendidikannya, yang ditugaskan untuk melakukan pembinaan terhadap umat Hidu rata-rata sudah memiliki ijazah S1, namun dibidang tugas dan fungsinya banyak yang tidak sesuai dengan bidang ilmu yang dimilikinya.

Untuk meningkatkan kualifikasi pendidikan penyuluh agama diperlukan upaya penanganan yang tidak saja secara konsepsional, akan tetapi juga perencanaan peningkatan pendidikan melalui seminar, workshop, dan loka karya, sehingga penyuluh Non PNS dalam memberi pembinaan di masyarakat mampu menunjukkan kemampuan keilimuan yang professional

Penyuluh agama Hindu non-PNS berdasarkan Keputusan Menteri Agama Republik Indonesia Nomor 164, Tahun 1996 tentang penyuluh agama yang dimaksud dalam KMA ini adalah penyuluh agama Hindu nonPNS adalah pembimbing umat Hindu dalam rangka pembinaan mental, moral, dan srada bhakti (ketakwaan) kepada Tuhan yang Maha Esa. Penyuluh agama Hindu non- PNS adalah seorang pemuka agama Hindu, pinandhita, sarathi banten yang bekerja menekuni bidang pelayanan, bimbingan, dan penyuluhan agama terhadap umat Hindu. Sebagian bidang tugas yang diketahui untuk melaksanakan pembinaan dan penyuluhan agama, adalah pembangunan masyarakat melalui bahasa agama.

Tanggungjawab penyuluh agama NonPNS merupakan tugas yang cukup berat artinya penyuluh selalu siap berhadapan dengan masyarakat yang ada dipelosok-pelosok ataupun didaerah terpencil, mengingat umat Hindu sangat mengharapakan pembinaan sebagai cerminan hidup. Penyuluh agama Non-PNS agar memiliki kemampuan untuk beradaptasi dan teguh dalam menemukan kesulitan yang merupakan suatu tantangan 
kerja bagi penyuluh agama Non-PNS dimana mereka ditempatkan untuk melakukan pembinaan kepada umat Hindu.

Keputusan Menteri Agama Republik Indonesia Nomor 164, Tahun 1996 tentang penyuluh agama Non-PNS menunjukkan ada beberapa hal yang harus dilaksanakan oleh penyuluh agama dalam rangka pembinaan kepada umat Hindu. Pertama mentaati segala peraturan perundang-undangan dan peraturan kedinasan yang berlaku, serta melaksanakan perintah-perintah kedinasan yang diberikan oleh atasan yang berhak. Kedua melaksanakan tugas dengan sebaik-baiknya serta memberikan pembinaan yang baik terhadap masyarakat sesuai dengan bidang tugasnya. Ketiga bersikap dan bertingkah laku yang sopan dan santun terhadap masyarakat, sesama penyuluh pegawai negeri sipil, dan atasannya.

Sementara yang diharapkan masyarakat adalah kinerja penyuluh agama Hindu nonPNS mampu memberikan pelayanan prima serta pembinaan yang optimal dan kentinu terhadap masyarakat Hindu di kabupaten Giamyar, terutama di desa-desa, mengingat tatanan kehidupan sosial umat Hindu di Gianyar yang penuh dengan kegiatan agama dan merupakan desa yang berwawasan budaya dan seni, dengan pembinaan yang kontinyu dilakukan oleh penyuluh, sehingga dapat meminimalisasikan suatu kemelut yang ada pada masyarakat Hindu, baik antar warga, antar kampung maupun antar pemuda. Apabila terjadi penguatan budaya kerja penyuluh agama Hindu Non-PNS dalam memberikan pembinaan terhadap umat Hindu, maka akan berdampak positif terhadap masyarakat Hindu di kabupaten Gianyar.

Tugas dan kewajiban penyuluh, pertama, penyuluh agama di Kementerian Agama kabupaten Gianyar telah memiliki tugas pokok untuk memberikan pembinaan kepada masyarakat, salah satu tujuannya adalah melayani, mengayomi, dan melindungi kepentingan, kebutuhan anggota masyarakat dalam suatu wilayah. Kedua, penyuluh nonPNS merupakan perpanjangan tangan oleh kepala seksi penyuluh yang ada di Kementerian Agama kabupaten Gianyar, mengingat daerah Ginyar merupakan daerah berbudaya dan seni, jangan sampai terjadi pergeseran nilai-nilai budaya dan seni, hal ini merupakan tantangan sangat tinggi bagi penyuluh.

Sementara kenyataan di lapangan saat ini menunjukkan bahwa pembinaan penyuluh agama Hindu oleh penyuluh Non-PNS di Gianyar belum dapat berjalan maksimal. Hal tersebut disebabkan beberapa hal. pertama, proses pembinaan umat Hindu di daerah Gianyar berjalan seadanya dalam arti belum berjalan sesuai dengan standar yang ditetapkan pemerintah. Kedua, penyuluh agama Hindu Non-PNS dalam pembinaan umat Hindu tidak maksimal bertatap muka, hanya saja membuat laporan bulanan secara rutin, sehingga masalah pembinaan hanya sebatas teori saja. Ketiga, hasil pembinaan oleh penyuluh NonPNS belum mampu menunjukkan hasil yang signifikan, dan Keempat honor yang diterima dibawah upah minimum regional.

Hal ini dapat dijadikan salah satu indikasi untuk menunjukkan rendahnya pembinaan umat oleh penyuluh agama non-PNS. Dalam kacamata ini dipandang bahwa para penyuluh agama Non-PNS Kementerian Agama kabupaten Gianyar, sebagai tenaga penyuluh yang bertugas memberikan pembinaan pendidikan agama dan keagamaan di masyarakat khusunya umat Hindu, hendaknya dapat memahami proses dan tujuan pendidikan.

\section{PEMBAHASAN}

\section{A. Bentuk Penguatan Budaya Kerja Penyuluh Agama Non-PNS dalan Pembinaan Umat.}

Budaya kerja yang terbentuk secara positif akan bermanfaat, karena setiap anggota dalam suatu organisasi membutuhkan ruang lingkup yang positif. Pekerjaan 
sebagai penyuluh agama non-PNS untuk memberikan pembinaan terhadap umat Hindu di Kabupaten Gianyar merupakan suatu misi untuk memajukan dan menyadarkan umat Hindu sebagai umat beragama yang harus memilki rasa yang tinggi untuk bertolerasi terhadap umat yang lain yang ada di seluruh Indonesia. Lemahnya penguatan budaya kerja akan mempengaruhi peradaban bangsa atau umat Hindu yang ada di nusantara khususnya di Kabupaten Ginayar, hal itu bisa terjadi baik, adanya perbedaan pandangan, pendapat, tenaga, dan pikiran.

Memperkuat budaya kerja penyuluh non-PNS di Kabupaten Ginayar membutuhkan waktu untuk merubahnya, maka untuk itu perlu adanya pembenahan-pembenahan yang dimulai dari sikap dan tingkah laku dari pemimpin dalam hal ini baik dari tataran Kementerian pusat maupun Kementerian daerah berdasarkan peraturan Mentri yang telah termuat dalam suatu keputusan.

Terbentuknya budaya kerja yang kuat diawali dari tingkat kesadaran pemimpin, karena besarnya hubungan antara pemimpin dengan bawahan sangat menentukan, konteks dalam hal ini kepala kantor Kementerian Agama Kabupaten Gianyar dengan penyuluh non-PNS, melalui desiplin, keterbukaan, saling menghargai, dan kerjasama. Kesuksesan dalam organisasi (Kementerian Agama) bermula dari disiplin dengan menerapkan nilai-nilai, dengan konsesten dalam penerapan aturan atau kebijakan dari pemerintah akan mendorong situasi keterbukaan, meningkatkan komunikasi horizontal dan vertikal. Bentuk penguatan budaya kerja penyuluh untuk memberikan pembinaa kepada umat antara laian:

\section{Kerja sama atau Gotong Royong}

Adalah usaha bersama yang dilakukan penyuluh agama, antara penyuluh agama PNS dengan penyuluh agama non-PNS dan yang lainnya, antar penyuluh agama non-PNS dengan masyarakat atau masyarakat dengan masyarakat untuk mencapai tujuan bersama. Kerja sama timbul saat seseorang menyadari bahwa mereka punya kepentingan bersama. Kerja sama menuntut adanya pembagian kerja dan keadilan, sehingga rencana kerja sama dapat tercapai dengan baik untuk mencapai tujuan bersama. Kerja sama akan bertambah kuat bila ada tantangan yang amat berat yang mesti diberikan solusi. Bentuk kerja sama seperti; kerukunan, loyalitas, adanya rasa memilki. Dengan kerja sama penyuluh agama akan memperkuat pembinaan kepada masyarakat, sehingga mampu merubah sumber daya manusia yang ada untuk meningkatkan produktivtas masyarakat.

\section{Keteladanan Penyuluh}

Keteladanan adalah perilaku yang terpuji dan disenangi karena sesuai dengan nilai-nilai kebaikan dan kebenaran. Menjalankan keteladanan merupakan cara yang bisa dilakukan para penyuluh agama dalam memberikan pembinaan kepada masyarakat untuk memberikan pendidikan agama keagaman berlandaskan visi dan misi.

Keteladanan penyuluh adalah “ leadingby exampk; being a model, role modeling" (berperan sebagai teladan). Penyuluh agama yang menjalankan peran keteladanan menjadi simbol yang nyata atas apa yang mereka harapkan untuk diraih pengikutnya" (1997:98). Para penyuluh memberi teladan melalui kejelasan semangat dan keyakinan melalui tindakan sehari-hari, menunjukkan visi penyuluh diwujudkan. Perilaku keteladanan para penyuluh adalah dengan menunjukkan kepada masyarakat binaannya mengenai apa yang harus mereka lakukan, dalam memberikan pembinaan yang cocok untuk dilakukan. Keteladanan ini dapat ditampilan dalam disiplin waktu, kepatuhan terhadap aturan, prosedur, tugas dan tanggung jawab sepenuhnya. 
Mengacu kepada Frigon dan Jackson (1999:10), keteladanan merupakan perilaku yang membawa kepada kredibilitas penyuluh agama. Hal yang diinginkan bawahan kepada pemimpin adalah kejujuran/baik hati, kompetensi, kredibilitas, dan visi yang dibagi. Sebagai teladan, kepala sekolah menyatakan kejujuran, konsisten, komitmen dan kredibel. Itulah pemimpin yang dipercaya yang sesuai kata dengan perbuatannya".

Kredibilitas bisa dipahami sebagai suatu kepercayaan atau keyakinan yang muncul terhadap penyuluh dari para masyarakati. Kredibilitas bukanlah karekteristik yang melekat pada diri seseorang (inherent), tetapi sesuatu yang diberikan masyarakat kepada penyuluhn. Suatu hal yang menimbulkan kredibilitas adalah komitmen pimpinan mewujudkan visi. Penyuluh agama non-PNS masa depan disyaratkan memiliki kredibilitas dan kapabilitas sehingga dapat diterima (akseptabilitas) dan mampu mengantarkan masyarakat pada perubahan, peningkatan mutu dan akuntabel.

Berdasarkan penjelasan di atas dapat disimpulkan bahwa keteladanan adalah perilaku penyuluh agama yang memberikan npembinaan hal-hal yang baik dalam melaksanakan tugas dan tanggung jawabnya, maupun kredilitas dan integritas pribadinya sebagai penyuluhn agama yang berusaha mewujudkan visi, tujuan dan sasaran sekolah.

\section{Profesional}

Professional merupakan bentuk penyuluh agama dalam membina masyarakat melalui memelihara, merawat, melatih, mengajar, menuntun, membimbing, dan memimpin. Namun penyuluh yang dimaksud di sini adalah sosok manusia bergelar sebagai panutan, yang dalam berbagai bidang memiliki kelebihan dan keistimewaan karena telah memiliki kualifikasi sebagai seorang penyuluh. Profesi adalah bidang pekerjaan yang dilandasi pendidikan keahlian keterampilan, kejuruan tertentu. Secara sederhana dapatlah diartikan bahwa syaratsyarat profesi adalah janji atau ketentuan yang harus dimiliki sekaligus dilaksanakan oleh orang yang memiliki keahlian tertentu (termasuk guru).

Semua jabatan profesi mempunyai ciri-ciri profesionalnya tersendiri, termasuk jabatan yang (mungkin) anda sandang saat ini yaitu guru dan penyuluh. Lebih jauh lagi profesi penyuluh agama adalah dasar dari persiapan dari semua kegiatan profesional lainnya.

Menggeluti bidang ilmu yang khusus. Anggota suatu profesi terutama profesi penyuluh menguasai bidang ilmu yang membangun keahlian mereka secara khusus.

Setiap anggota profesi harus meningkatkan kemampuannya, tidak terkecuali profesi guru saja melainkan penyuluh agama pun dapat memberikan pelayanan secara maksimal kepada masyarakat melalui pembinaan.

Subjek penyuluh adalah manusia yang memiliki kemauan, pengetahuan, emosi, dan perasaan serta dapat dikembangkan sesuai dengan potensinya. Sementara itu pembinaan dilandasi oleh nilai-nilai kemanusiaan yang menghargai martabat manusia.

\section{Kemandirian}

Kemandirian merupakan sikap atau perilaku dan mental yang memungkinkan penyuluh untuk bertindak dalam melakukan pembinaan-pembinaan di masyarakat secara bebas, dan bermanfaat, dengan berusaha melakukan sesuatu dengan jujur, benar atas dorongan dirinya sendiri, sesuai dengan tugas dan kewajibannya sebagai penyuluh, sehingga dapat memberikan pembinaan yangsangat bermanfaat bagi kehidupan masyarakat yang ada di kabupaten Gianyar.

Penyuluh non-PNS yang memiliki jiwa kemandirianantara lain; (1) memiliki kemampuan untuk selalu berusaha dan 
memilki inisiatif, (2) memilki kemampuan untuk melaksanakan tugas dan tanggungjawab sebagai penyuluh, (3) memperoleh kepuasan dari hasil pembinaan yang dilakukan di masyarakat, dan (4) memilki kemampuan untuk menyelesaikan segala permaslahan yang ada di masyarakat.

Inti pembinaan terjadi pada prosesnya, yakni situasi di mana terjadi dialog antara masyarakat ke arah yang dikehendaki oleh penyuluh agar selaras dengan nilai-nilai yang dijunjung masyarakat. Untuk memperkuat budaya kerja penyuluh agama non-PNS dalam pembinaan umat Hindu dapat dilakukan melalui;

\section{B. Faktor-faktor Yang Dapat Mempengaruhi Kuatnya Budaya Kerja}

1. Perilaku Kepala Kementerian Agama.

Perilaku berupa tindakan yang nyata dari pimpinan biasanya akan menjadi cerminan penting bagi bawahan atau pengawai dalam hal ini adalah penyuluh agama non-PNS untuk membangun suatu peradaban umat beragama, sehingga akan mencul suatu kesadaran yang dapat saling harga menghargai diantara umat beragama.

\section{Budaya institusi.}

Setiap lembaga atau institusi memiliki budaya kerja yang telah dibangu sejak lama untuk, sebagai tuntunan bagi generasi berikutnya. Dengan memilki budaya kerja yang kua, akan dapat membangun institusi yang kokoh untuk menciptakan sumber daya manusia yang baik, dengan memilki sumber dayamanusia yang baik akan dapat memajukan suatu wilayah atau lembaganya masing-masing.

\section{Kejelasan Misi dalam Kantor Kementerian Agama. \\ Dengan mengetahui misi secara jelas,} maka akan diketahui secara utuh dan jelas suatu pekerjaan yang seharusnya dikerjakan oleh pegawai atau penyuluh agama non-PNS selaku kewajibannya. Menjalankan kewajiban adalah sebagai swadharma yang mulia untuk membangun suatu Negara maupun wilayah.

\section{Keteladanan Pemimpin}

Pemimpin harus mampu memberikan contoh budaya semangat kerja kepada para penyuluh agama baik PNS maupun NonPNS berserta pegawai yang lainnya. Dengan semangat kerja yang tinggi akan berdampak terhadap kemajuan pembangunan yang telah terwujud sebagai kemajuan bangsa.

\section{Motivasi Kerja}

Setiap pekerjaan membutuhkan dorongan untuk turut memecahkan masalahmasalah yang dialami oleh institusi atau Kementerian Agama yang lebih inovatif. Keberhasilan dalam menyelesaikan masalah berarti pimpinan telah mampu melaksanakan manajemen pada suatu lembaga yang dipimpin, sehingga permasalahan dapat teratasi. Melaksanakan manajemen yang baik akan memperlancar kinerja pada suatu instansi, dan memperkokoh budaya kerja.

Dalam rangka mengaktualisasikan budaya kerja sebagai ukuran sistem nilai dalam bekerja yang pertama kali harus diupayakan adalah penanaman dalam sikap mental penyuluh agama non-PNS yang meliputi pemahaman dan pelaksanaan dalam sikap dan pelaksanaan pembinaan terhadap umat Hindu.

Selain itu perilaku pemimpin (Kepala Kantor) merupakan faktor yang mempengaruhi kuatnya budaya kerja dalam suatu lembaga pemerintah, keteladanan sikap untuk dapat dijadikan contoh dan panutan oleh semua bawahan, juga kebijakan dalam menentukan arah, tujuan serta visi dan misi suatu lemnbaga yang akan dijakdikan landasan dalam pelaksanaan budaya kerja. 


\section{Tujuan dan Manfaat Budaya Kerja}

Budaya kerja secara umum memilki tujuan untuk mengubah sikap dan juga perilaku sumber daya manusia yang ada, agar dapat meningkatkan produktivitas kerja untuk menghadapi berbagai tantangan dimasa yang akan datang. Dalam penelitian ini penguatan budaya kerja bagi penyuluh agama nonPNS dalam pembinaan umat Hindu, adalah menanamkan sikap dan perilaku, sehingga mengasilkan kerja yang nyata dan baik untuk mampu mengatasi segala munculnya permasalahan yang dihadapi umat Hindu saat terdapat ini.

Di dalam budaya kerja terdapat etos kerja, budaya kerja dan etos kerja adalah dua hal yang sangat penting dan saling berkaitan, karena pekerjaan tanpa etos kerja, maka tidak akan selesai, sedangkan etos kerja ini sangat dibutuhkan oleh penyuluh agama Hindu, sebagai landasan penguatan budaya kerja.

Keberhasilan budaya kerja penyuluh dapat dilihat dari peningkatan tanggung jawab, peningkatan kedisiplinan, dan kepatuhan pada norma atau aturan, terjalin komunikasi dan hubungan yang harmonis dengan semua pegawai, peningkatan partisivasi dan kepedulian peningkatan kesepakatan untuk pemecahan permasalahan yang dihadapinya.

Budaya kerja memiliki tujuan untuk mengubah sikap dan perilaku sumber daya manusia yang ada agar dapat mengasilkan kerja dan menghadapi berbagai tantangan dimasa yang akan datang. Peningkatan kenerja penyuluh untuk mencapai hasil bisa dilakukan melalui; 1) penyuluh dapat memahami pola kerja dalam pembinaan, 2) mengimplementasikan pola kerja yang dilakukan dalam pembinaan, 3) menciptakan suasana yang harmonis dengan partner kerja, 4) membangun rasa kerja sama terhadap rekan kerja dalam team, 5) bisa beradaptasi dengan lingkungan secara baik.

Sedangkan manfaat budaya kerja penyuluh agama non-PNS dalam melakukan pembianaan antara lain; 1). Menjamin hasil kerja dengan kualitas baik, 2). Keterbukaan antara indivvidu dalam melakukan pembinaan, 3). Saling bekerja sama dalam mengatasi masalah, 4) menimbulkan rasa kebersamaan antara individu dengan individu lain dalam pekerjaan, dan 5) cepat menyesuaikan diri dengan perkembangan yang telah terjadi. Budaya kerja merupakan sikap hidup, serta cara hidup bekerja yang bertumpu pada nilainilai yang berlaku umum, sehingga kuatnya budaya kerja penyuluh agama teletak pada sebuah nilai dan norma-norma yang berlaku secara umum. Budaya kerja merupakan realisasi nilai yang perlu dimiliki setiap individu untuk senantiasa bekerja, berhasil dan terpuji.

\section{Fungsi Budaya Kerja Penyuluh}

Fungsi budaya kerja secara umum untuk membangun keyakinan atau menanamkan nilai-nilai tertentu suber daya manusia, sikap dan perilaku yang konsisten serta komitmen dalam membiasakan suatu cara kerja di lingkungan kerja masing-masing. Penyuluh Agama non-PNS melakukan pembinaan terhadap umat Hindu di Kabupaten Gianyar dengan memilki tekad sebagai berikut.

1. Memilki sebuah identitas (simbol dan harapan) dalam konteks ini penyuluh Agama telah memilki potensi untuk melakukan pembinaan, sehingga masyarakat merasa berbangga dan menaruh respek terhadap kemampuan penyuluh.

2. Kestabilan dalam organisasi penyuluh, sehingga secara internal seluruh masyarakat yang dibina merasa tenang dan yakin, dan secara ekternal yang berdampingan merasa memilki bersama.

3. Memilki alat pendorong merupakan motivasi, sehingga mampu menjadi dasar untuk mencapai tujuan dari pembinaan umat Hindu. 
4. Komitmen dalam organisasi penyuluh, sehingga mampu sebagai katalisator dalam memberi komitmen untuk pelaksanaan berbagai ide atau suatu rencana strategis. Dengan adanya keyakinan yang kuat dalam merefleksikan nilai-nilai tertentu, misalkan; membiasakan kerja berkualitas sesuai dengan standar, kerja secara efektif-efisien dan produktif merupakan awal dari budaya kerja yang baik, membiasakan semua kerja tersebut merupakan suatu penguatan budaya bagi penyuluh untuk mencapai hasil yang diharapkan.

Tujuan fundamental budaya kerja adalah untuk membangun sumber daya manusia, agar berprilaku modern dalam bekerja dan berinteraksi komunikasi dengan orang lain secara efektif dan efisien, sehingga tertanam penguatan kerja yang tinggi dan desiplin. Dengan membiasakan kerja yang berkualitas sesuai dengan standar maka penyuluh Agama non-PNS menjadi tenaga yang bernilai dan berguna, dapat memberikan nilai tambah bagi orang lain atau masyarakat yang dibina.

Budaya kerja mempunyai arti yang sangat mendalam,karena akan merubah sikap dan perilaku sumber daya manusia untuk mencapai produktivitas kerja yang lebih tinggi dalam menghadapi tantangan masa depan. Disamping itu masih banyak lagi manfaat yang muncul seperti kepuasan kerja meningkat, hubungan antar pegawai dan penyuluh lebih akrab, disiplin meningkat, mengurangi pemborosan, tingkat absensi menurun, terus belajar, dan ingin memberikan yang terbaik bagi orang lain.

Berdasarkan pandangan mengenai manfaat budaya kerja penyuluh pada Kementerian Agama Kabupaten Gianyar, disimpulkan bahwa manfaat budaya kerja adalah sebenarnya untuk meningkatkan kualitas sumber daya penyuluh agama NonPNS itu sendiri, kualitas hasil kerja sesuai yang diharapkan, karena selama ini upah yang diterima penyuluh non-PNS sangat minim dan tidak memenuhi standar Upah Minimum Regioal daerah.

Dengan menjalankan kewajiban sebagai penyuluh mesti dilandasi dengan kesadaran sebagai penguatan budaya kerja. Penguaan budaya kerja akan dapat membangun insaninsan yang bermoral dan membawa umat Hindu kearah yang lebih menyadarkan diri, sehingga akan mampu bersaing dan merguna bagi nusa dan bangsa. Penyuluh non-PNS yang ada di Kabupaten Gianyar mampu mengatasi segala permasalahan umat Hindu, hal ini merupakan harapan masyarakat Hindu.

\section{E. Dedikasi dalam Budaya Kerja Penyuluh Non-PNS}

Secara umum budaya kerja bersentuhan langsung dengan aspek pelayanan terhadap pembinaan umat Hindu sesuai dengan setandar pekerjaan yang dilakukan oleh penyuluh agama non-PNS. Penyuluh agama non-PNS didalam memberikan pelayanan yang baik kepada masyarakat maka diperlukan persyaratan sebagai berikut.

1. Kreativitas dan kepekaan, yaitu mengembangkan pekerjaan secara dinamis dapat mendorong ke arah efisien dan efektivitas. Penyuluh agama Hindu non-PNS dimanapun mendapatkan wilayah binaan, selayaknya mengembangkan sikap dan tindakan efektif dan efisien, pekerjaan berupa pembinaan dapat dilaksanakan secara efektif dan efisien jika didasari oleh adanya kemampuan melakukan pembinaan secara kreatifitas dan kepakaan yang tinggi, tanpa adanya kreatifitas dan kepekaan penyuluh akan sulit dapat melakukan pembinaan secara efektif.

2. Disiplin dan keteraturan kerja, bekerja sebagai penyuluh agama non-PNS mengacu pada standar oprasional 
prosedur (SOP). Setiap penyuluh melakukan pembinaan terhadap umat Hindu harus memilki standar oprasional prosedur (SOP), melalui prosedur kerja dalam pembinaan distandarisasikan, maka akan dapat materi pembinaan yang jelas, jika kesalahan pada standar oprasional prosedur (SOP) maka materi pembinaan yang disampaikan akan merusak mental masyarakat.

3. Dedikasi dan loyalitas, dedikasi dan loyalitas yang diberikan kepada visi dan misi lembaga (kementerian) tidak kepada kepala kantor atau pribadi pimpinan. Loyalitas diberikan kepada lembaga akan memperkuat tatanan yang ada pada lembaga demi kemajuan umat.

4. Semangat dan motivasi, penyuluh agama dalam bekerja melakukan pembinaan yang didorong oleh keinginan yang baik dan kuat sangat menentukan dalam penguatan budaya kerja untuk mencapai tujuan yang hendak dicapai.

Penguatan budaya kerja penyuluh agama non-PNS untuk melakukan pembinaan, sesungguhnya muncul dari dirinya atas kesadaran dan juga perlu dibentuk, karena pada dasarnya budaya adalah sekumpulan nilai dan pola perilaku yang dipelajari, diajarkan, dan dimiliki bersama, oleh penyuluh agama nonPNS serta diwarisi dari generasi kegenerasi berikutnya.

Budaya kerja sangat penting peranannya dalam mendukung terciptanya suatu organisasi pemerintah yang efektif, dapat berperan dalam menciptakan jati diri, mengembangkan keikutsertaan pribadi penyuluh agama menyajikan pedoman untuk materi pembinaan. Budaya kerja sangat ditentukan oleh nilai-nilai yang dianut oleh penyuluh agama, nilai-nilai dalam suatu organisasi pemerintah sangat ditentukan oleh nilai-nilai yang dianut oleh penyuluh itu sendiri. Membangun budaya memerlukan waktu karena yang ditata adalah sikap dan perilaku manusia. Perlu adanya rule model, perlu konsisten manajemen puncak. Ketika sebuah organisasi pemerintah mengalami transpormasi baik pertumbuhan yang spektakuler, maka budaya yang dimilki penyuluh agama mengalami berubah secara perlahan.

\section{SIMPULAN}

Bentuk penguatan budaya kerja penyuluh agama Hindu non- PNS Kementerian Agama Kabupaten Gianyar dalam pembinaan masyarakat Hindu di Kabupaten Gianyar menunjukkan hal-hal sebagai berikut; (a) adanya sikap kerjasama dan kegotongroyongan, kerja sama antara penyuluh agama PNS dengan penyuluh agama non-PNS dan yang lainnya, antar penyuluh agama non-PNS dengan masyarakat atau masyarakat dengan masyarakat untuk mencapai tujuan bersama; (b) keteladannan penyuluh, melaksanakan tugas sebagai penyuluh bentuk keteladanan merupakan cara yang bisa dilakukan para penyuluh agama dalam memberikan pembinaan kepada masyarakat untuk memberikan pendidikan agama keagaman berlandaskan visi dan misi; (c) professional, profesi adalah bidang pekerjaan penyuluh yang dilandasi pendidikan keahlian keterampilan, kejuruan tertentu. Secara sederhana dapatlah diartikan bahwa syarat-syarat profesi adalah janji atau ketentuan yang harus dimiliki sekaligus dilaksanakan oleh penyuluh yang memiliki keahlian tertentu (termasuk guru); (d) kemandirian, kemandirian merupakan sikap atau perilaku dan mental yang memungkinkan penyuluh untuk bertindak dalam melakukan pembinaan-pembinaan di masyarakat secara bebas, dan bermanfaat, dengan berusaha melakukan sesuatu dengan jujur, benar atas dorongan dirinya sendiri, sesuai dengan tugas dan kewajibannya sebagai penyuluh, sehingga dapat memberikan pembinaan yang sangat bermanfaat bagi kehidupan masyarakat yang ada di kabupaten Gianyar. 


\section{DAFTAR PUSTAKA}

Badudu-Zin. 2001. Pembinaan Karier Pegawai. Jakarta: Raja Gerafindo Persada.

Barata. 20004. Pelayanan Prima Pelanggan. Surabaya: Paramita.

Cudamani. 1990. Pengantar Agama Hindu Untuk Perguruan Tinggi. Jakarta: Yayasan Dharma Sarathi.

Damsar. 2015. Pengantar Teori Sosiologi. jakarta: PT Aditya Andrebina Agung.

Dwiyanto, A. 2002. Reformasi Birokrasi Publik di Indonesia. Edisi Pertama. Pusat Studi Kependudukan dan Kebijakan, Yogyakarta: UGM.

Effendi dalam Widodo. 1999. Pembinaan Pendidikan Keimanan. Surabaya: Paramita.

Nasir, 1999. Teori-Teori Soisial dan Budaya, Jakarta: Hanoman Sakti.

Netra, Anak Agung Gde Oka, 1995, Tuntunan Dasar Agama Hindu. Jakarta: Hanoman Sakti.

Peraturan Pemerintah RI No. 55, Tahun 2007 Tentang Pendidikan Agama dan Pendidikan Keagamaan. Direktorat Jenderal Islam Departemen Agama RI.

Undang-Undang Nomor 20, Tahun 2003 tentang Sistem Pendidikan Nasional, Jakarta: Ekajaya. 